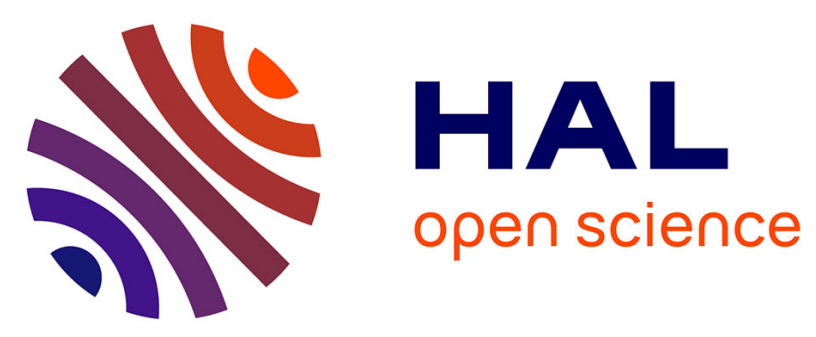

\title{
Covalent immobilization of glucose oxidase on mesocellular silica foams: Characterization and stability towards temperature and organic solvents
}

\author{
Noemie Balistreri, Dorian Gaboriau, Claude Jolivalt, Franck Launay
}

\section{To cite this version:}

Noemie Balistreri, Dorian Gaboriau, Claude Jolivalt, Franck Launay. Covalent immobilization of glucose oxidase on mesocellular silica foams: Characterization and stability towards temperature and organic solvents. Journal of Molecular Catalysis B: Enzymatic, 2016, 127, pp.26-33. 10.1016/j.molcatb.2016.02.003 . hal-01281753

\section{HAL Id: hal-01281753 \\ https: / hal.sorbonne-universite.fr/hal-01281753}

Submitted on 2 Mar 2016

HAL is a multi-disciplinary open access archive for the deposit and dissemination of scientific research documents, whether they are published or not. The documents may come from teaching and research institutions in France or abroad, or from public or private research centers.
L'archive ouverte pluridisciplinaire HAL, est destinée au dépôt et à la diffusion de documents scientifiques de niveau recherche, publiés ou non, émanant des établissements d'enseignement et de recherche français ou étrangers, des laboratoires publics ou privés. 


\section{Covalent immobilization of glucose oxidase on mesocellular silica foams:}

\section{characterization and stability towards temperature and organic solvents}

N. Balistreri ${ }^{a, b}$, D. Gaboriau ${ }^{a, b}$, C. Jolivalt ${ }^{a, b, *}$ and F. Launay ${ }^{a, b}$

a- Sorbonne Université, UPMC Univ Paris 06, UMR 7197, Laboratoire de Réactivité de

Surface, 4 Place Jussieu, F-75005, Paris, France

b. CNRS, UMR 7197, Laboratoire de Réactivité de Surface, 4 Place Jussieu, F-75005, Paris, France

e-mail addresses :

noemie.balistreri@upmc.fr

dorian.gaboriau@cea.fr

franck.launay@upmc.fr

*Corresponding author: claude.jolivalt@upmc.fr

Keywords: mesoporous silica; immobilization; glucose oxidase; hydrogen peroxide production ; stability

Abstract

Glucose oxidase (GOx) immobilization onto mesoporous SBA-15 silica and two mesocellular foams (MCF) characterized by similar surface area and pore volumes but different pore/cell dimensions was examined. The covalent grafting of the enzyme through amide bonds was evidenced by controlling $\mathrm{pH}$ conditions, thus preventing GOx leaching. The immobilized protein activity was found to be significantly higher for the mesocellular foam with both cells and windows size larger than the enzyme dimensions. The Michaelis-Menten parameter $\mathrm{K}_{M}$ 
for the immobilized GOx was similar to that of the free enzyme. GOx exhibited higher thermal stability when immobilized on the mesocellular foam compared to the free enzyme. The activity decay of GOx in presence of water soluble organic solvents, i.e. acetonitrile or methanol, was studied. At $50^{\circ} \mathrm{C}$, half of the immobilized GOx activity could be retained in 40 v/v. \% MeOH / acetate buffer. 


\section{Introduction}

Current existing production processes for commodity chemicals have to be revised because of the increasing concern of the chemical industry towards sustainability issues which drives the impetus of green chemistry $[1,2]$. This includes the field of oxidation where peracids could be replaced by more environment-friendly reagents such as hydrogen peroxide, whose reduction produces water instead of carboxylic acids by-products [3]. In situ controlled production of hydrogen peroxide using palladium as a catalyst has been shown to limit $\mathrm{H}_{2} \mathrm{O}_{2}$ disproportionation that is detrimental to the oxidation yields [4-6]. Biocatalysis using glucose oxidase (GOx), an enzyme catalyzing the reduction of $\mathrm{O}_{2}$ to $\mathrm{H}_{2} \mathrm{O}_{2}$, concomitantly to the oxidation of glucose to gluconic acid, is an alternative method for the in situ production of $\mathrm{H}_{2} \mathrm{O}_{2}$. Several homogeneous [7] or heterogeneous [8] chemo-enzymatic systems (also called tandem catalysts) combining biocatalytic hydrogen peroxide production and subsequent oxidation of alkene to epoxides using inorganic catalysts have been described. It is interesting to note that in such processes, the by-production of gluconic acid can be valorized as it is widely used in the food industry $[9,10]$ as a preservative.

Enzyme immobilization on a solid support often prevails in biotransformation processes because it allows the recycling of the catalyst and enhances operational and storage stability, thus reducing the costs. Silica and alumina supports with high surface area and chemical and thermal stability [11] are of particular interest for tandem catalysis because they are suitable for hosting both the enzyme and the metal catalyst. Vennestrøm et al. have reported the immobilization of GOx onto TS-1, a redox-active molecular sieve with MFI framework [8], for the successful epoxidation of allyl alcohol to glycidol. However, as TS-1 micropores diameter is only $0.6 \mathrm{~nm}, \mathrm{GOx}$, active as a globular dimer with dimensions 
$6.0 \times 5.2 \times 7.7 \mathrm{~nm}^{3}$, was likely to be localized outside the pores. Consequently, hydrogen peroxide production took place on the external surface of the material while most of the epoxidation occurred inside the pores, close to the titanium sites. An alternative method would be to locate both the enzyme and the metal catalyst inside the porosity, thus minimizing the distance between the $\mathrm{H}_{2} \mathrm{O}_{2}$ production and epoxidation sites with several advantages: i) no diffusion limitation of $\mathrm{H}_{2} \mathrm{O}_{2}$, ii) decrease of $\mathrm{GOx}$ denaturation by $\mathrm{H}_{2} \mathrm{O}_{2}$ as well as of $\mathrm{H}_{2} \mathrm{O}_{2}$ losses by disproportionation because of the rapid consumption of hydrogen peroxide. Suitable supports for that purpose could be mesoporous silica such as MCM-type, SBA-type materials or mesocellular silica foams synthesized by surfactant templating techniques. These materials have been successfully used to immobilize proteins [12-24] for applications in analysis [25] or sensors [26-28], as recently reviewed by Zhou and Hartman [29]. The large pore volume, controllable and well-defined pore size of these mesoporous materials ensures the diffusion of both reagents and products inside the pores, even allowing the transformations of bulky reactants. Different immobilization methods including entrapment, adsorption and chemical binding are used to immobilize enzymes [30]. Adsorption is often favored because it is simple and is expected to induce limited modification of the protein structure $[23,31]$. However it is also associated with the problem of enzyme leaching in addition to non-specific protein-silicate binding through hydrophobic interactions [32]. Therefore, functionalization of mesoporous materials, usually amination through amino silane, is a widely used method to covalently immobilize proteins $[17,32]$ and among them GOx $[21,24]$. In a recent approach, the crosslinking of adsorbed proteins in situ inside the pores of mesoporous materials was also found to be very effective in preventing enzymes, respectively lipase, invertase and choloroperoxidase/GOx, leaching 
$[17,21,33,34]$. In addition, several methods such as combination of differential interference contrast and fluorescence microscopy [35] or small-angle neutron scattering [36] demonstrated that the enzymes, respectively lipase and chloroperoxidase, are confined in the nanoscale pores of the mesoporous support.

So mesoporous siliceous material, with pores large enough to accommodate proteins and functional groups able to sequester active enzyme are available. However, no general answer can be derived regarding an optimized immobilization protocol for a given enzyme or a targeted biotransformation reaction remains an issue.

The present work focused on the immobilization of GOx on a functionalized siliceous support and compared both adsorption and covalent immobilization methods. The main goal of this study is to maximize the covalent coupling at the expense of adsorption and the operational stability thanks to the minimization of enzyme leaching. Indeed, both covalent and adsorption immobilization processes take place when mixing the support and the enzyme but the issue of minimizing the remaining non-covalently bound protein on the surface is seldom addressed in the literature. Two MCFs materials were tested as models of ultra large open porosity with connected cells large enough to host glucose oxidase dimers. These materials were compared to SBA-15 type support, whose pores are smaller than the GOx dimensions. In addition, as one of the targeted application of the so-produced hydrogen peroxide is alkene epoxidation that usually takes place at temperatures higher than room temperature and often requires an apolar environment in case of hydrophobic alkenes, thermal stability of the immobilized GOx as well as its efficiency in water/acetonitrile and water/methanol mixtures will be studied by measuring GOx activity, i.e its ability to produce hydrogen peroxide. 


\section{Experimental}

\subsection{Chemicals}

Tetraethyl orthosilicate (TEOS, 99\%, Aldrich), triblock copolymer $\mathrm{EO}_{20} \mathrm{PO}_{70} \mathrm{EO}_{20}$ (Pluronic P123, Aldrich), 1,3,5-trimethylbenzene (TMB, 97\%, Acros), ammonium fluoride $\left(\mathrm{NH}_{4} \mathrm{~F}, 98 \%\right.$, Fluka), hydrochloric acid ( $\mathrm{HCl}, 37 \%, \mathrm{VWR}), 3$-aminopropyltriethoxysilane (APTES, 99\%, Aldrich), anhydrous toluene (VWR), acetone (VWR), ethanol (VWR), methanol (Sigma Aldrich), acetonitrile (Sigma Aldrich), D-(+)-glucose (99.5\%, Sigma), sodium acetate (anhydrous, 99\%, Alfa Aesar), potassium dihydrogen phosphate $\left(\mathrm{KH}_{2} \mathrm{PO}_{4}, 99.5 \%\right.$, Riedel-deHaën), di-potassium hydrogen phosphate $\left(\mathrm{K}_{2} \mathrm{HPO}_{4}\right.$, anhydrous, Merck), 2,2'-azino-bis(3ethylbenzothiazoline-6-sulfonic acid) diammonium salt (ABTS, 98\%, Sigma), Nhydroxysuccinimid (NHS, 97\%, Aldrich), 1-ethyl-3-(3-dimethylamino-propyl)carbodiimide hydrochloride (EDC, Sigma), peroxidase from horseradish (HRP type VI, 253 units/mg solid, Sigma), glucose oxidase from Aspergillus niger (type X-S, 120 units/mg solid, Aldrich) were used as received.

\subsection{Synthesis of $S B A-15$}

SBA-15 silica was synthesized according to the method described by Zhao et al. [37]. Briefly, $4 \mathrm{~g}$ of $\mathrm{P} 123$ were stirred for $2 \mathrm{~h}$ at $40^{\circ} \mathrm{C}$ in $150 \mathrm{~mL}$ of $1.6 \mathrm{M}$ aqueous $\mathrm{HCl}$. Then, $9 \mathrm{~mL}(40$ mmol) of TEOS were slowly added under stirring. The resulting gel was aged at $40^{\circ} \mathrm{C}$ for $24 \mathrm{~h}$, and then hydrothermally treated at $100^{\circ} \mathrm{C}$ for $24 \mathrm{~h}$ in a FEP ${ }^{\circledR}$ bottle. The resulting material was filtered, washed thoroughly with deionized water and dried at $100^{\circ} \mathrm{C}$ for $24 \mathrm{~h}$. Finally, 
the surfactant was removed by calcination at $550^{\circ} \mathrm{C}$ in air for $6 \mathrm{~h}$ after using a $24^{\circ} \mathrm{C}$ per $\mathrm{h}$ ramp.

\subsection{Synthesis of MCFs (mesocellular foams)}

Two samples of pure silica MCFs (MCF1 and MCF2) were prepared by a hydrothermal method developed by Stucky et al. [38]. Hence, $4 \mathrm{~g}$ of P123 were dissolved in $150 \mathrm{~mL}$ of 1.6 $\mathrm{M}$ aqueous $\mathrm{HCl}$ at $40^{\circ} \mathrm{C}$. TMB was then slowly added and the resulting solution stirred vigorously $(1000 \mathrm{rpm})$ at $40^{\circ} \mathrm{C}$ for $2 \mathrm{~h}$. Then $9 \mathrm{~mL}(40 \mathrm{mmol})$ of TEOS were slowly introduced while stirring. The resulting gel was aged in a water bath at $40^{\circ} \mathrm{C}$ for $24 \mathrm{~h}$. In the case of MCF2, $48 \mathrm{mg}$ of $\mathrm{NH}_{4} \mathrm{~F}$ were also added. Then the mixture was hydrothermally treated for 24 $\mathrm{h}$ at $100^{\circ} \mathrm{C}$ in a $\mathrm{FEP}^{\circledR}$ bottle. The resulting material was filtered, washed thoroughly with deionized water and dried at $60^{\circ} \mathrm{C}$ for $24 \mathrm{~h}$. Finally, the surfactant was removed by calcination at $550^{\circ} \mathrm{C}$ in air for $6 \mathrm{~h}$ after using a $24^{\circ} \mathrm{C}$ per $\mathrm{h}$ ramp.

\subsection{Functionalization of SBA-15 MCF1 and MCF2 silicas with APTES}

Prior to the grafting step, $1 \mathrm{~g}$ of siliceous material was activated at $350^{\circ} \mathrm{C}$ for $3 \mathrm{~h}$ in air. The material was then transferred into a dried round-bottom flask equipped with a septum and a condenser. Dry toluene $(50 \mathrm{~mL})$ was rapidly introduced and the resulting suspension was vigorously stirred with a glass coated magnetic stirrer under inert gas. APTES $(1.0 \mathrm{~mL}, 4$ mmol) was added dropwise and the mixture was stirred for $1 \mathrm{~h}$ and then refluxed for $24 \mathrm{~h}$ still under inert gas. After cooling, the resulting material was recovered by suction filtration and washed with toluene $(30 \mathrm{~mL})$, acetonitrile $(30 \mathrm{~mL})$ and ethanol $(30 \mathrm{~mL})$. The white solid was then dried at $60^{\circ} \mathrm{C}$ under air. Finally, the excess of APTES was extracted by dichloromethane (Soxhlet) for $24 \mathrm{~h}$ and then dried at $60^{\circ} \mathrm{C}$ under air. 


\subsection{Characterization of mesoporous materials}

$\mathrm{N}_{2}$ sorption isotherms were measured on a Micromeritics ASAP 2020 instrument at $-196{ }^{\circ} \mathrm{C}$. Before, samples were degassed overnight at $120^{\circ} \mathrm{C}$. The total pore volume was estimated from the amount of $\mathrm{N}_{2}$ adsorbed at $\mathrm{P} / \mathrm{P}_{0}=0.99$. The $\mathrm{BET}$ specific surface area, $\mathrm{S}_{\mathrm{BET}}$ was obtained from the adsorption data in the relative pressure range of $P / P_{0}=0.05-0.25$. The mean pore diameter of SBA-15 was determined using the BJH model [39]. MCFs pores are considered to be of the ink-bottle-type interconnected by narrow windows. The cells and windows diameters were estimated using the modified Broekhoff-de-Boer (BdB)-FHH modified method where FHH refers to the Frenkel-Halsey-Hill form of the isotherms [40, 41]. The cell sizes were obtained from the adsorption branches of isotherms, while desorption branches gave the window sizes. Imaging of the silica particles were performed by Transmission Electron Microscopy using a JEOL JEM-100 CX II microscope operating at 100 kV. Thermogravimetric (TG) analysis were carried out on a STD Q600 apparatus from TA ${ }^{\circledR}$ instruments under $100 \mathrm{~mL} / \mathrm{min}$ of air with a ramp rate of $10^{\circ} \mathrm{C} / \mathrm{min}$. Small-angle X-ray diffraction measurements were performed on a Bruker D8 Advanced instrument with the $\mathrm{Cu}$ K $\alpha$ radiation $(\lambda=1,5418 \AA)$. FTIR spectra were recorded on a Bruker Vector 22 . Electrophoretic mobility and Zeta potentials of mesoporous materials were analyzed using a laser Doppler Malvern Zetasizer instrument. UV-Vis. transmission spectroscopy and kinetic studies were performed with an Uvikon 990 (Kontron) instrument.

\subsection{Immobilization of GOX on aminopropyl-functionalized materials}

EDC and NHS (1 : 1 molar ratio) were used as coupling agents (C.A.). GOx was incubated at room temperature for $30 \mathrm{~min}$ in $2 \mathrm{~mL}$ of $10 \mathrm{mM}$ phosphate buffer at $\mathrm{pH}=6$ in presence of 
different C.A./GOx molar ratios: 0 (for adsorption studies) to 1,600 according to the experiment (for each experiment this ratio and associated concentrations are indicated in the text). Meanwhile, the aminopropyl functionalized support (about $20 \mathrm{mg}$ ) was suspended in $2 \mathrm{~mL}$ of $100 \mathrm{mM}$ phosphate buffer at $\mathrm{pH}=8$, then mixed with the solution of GOx and C.A.. The final $\mathrm{pH}$ was 7.6. The resulting mixture was kept overnight at room temperature with a mild shaking at $200 \mathrm{rpm}$. Later, the solid was recovered by centrifugation and washed 2 times with $4 \mathrm{~mL}$ of $100 \mathrm{mM} \mathrm{pH}=8$ phosphate buffer for covalent immobilization (i.e in the presence of C.A.). For GOx adsorption experiments (i.e in the absence of C.A.), several washings were performed at various $\mathrm{pH}$ values, as indicated in the text. In all cases, no GOx activity was detected in the supernatant after the second washing. Immobilized GOx was then stored in $25 \mathrm{~mL}$ of $100 \mathrm{mM}$ acetate buffer at $\mathrm{pH}=6$.

\subsection{Assay of the GOX Activity}

GOx catalyzes glucose oxidation to gluconolactone and the concomitant reduction of $\mathrm{O}_{2}$ to $\mathrm{H}_{2} \mathrm{O}_{2}$. The kinetics of the GOx catalyzed-reaction was followed through the subsequent reduction of hydrogen peroxide by horseradish peroxidase (HRP) in the presence of ABTS, thus affording its oxidized form, $A B T S_{\text {ox. }}$ As $A B T S_{\text {ox }}$ absorbs at $420 \mathrm{~nm}$, spectroscopic measurements were conducted. The concentrations of the reaction mixture in the spectrophotometric cuvette were: $500 \mathrm{mM}$ glucose, $8.6 \mathrm{mM} \mathrm{ABTS}$ and $0.01 \mathrm{mg} / \mathrm{mL} \mathrm{HRP} \mathrm{(3}$ $\mathrm{U} / \mathrm{mL}$ ) in aerated $100 \mathrm{mM}$ sodium acetate buffer, $\mathrm{pH}=6$. Activity experiments were performed at $30^{\circ} \mathrm{C} .10 \mu \mathrm{L}$ of the GOx solution to be tested was added in $990 \mu \mathrm{L}$ of the reaction mixture $\left(V_{\text {total }}=1 \mathrm{~mL}\right)$. These conditions are suitable up to $2 \mathrm{U} / \mathrm{mL}$ of GOx activity, 
the maximal linear rate for ABTS oxidation being observed. One unit $(U)$ was defined as 1 $\mu \mathrm{mol}$ of hydrogen peroxide produced per minute.

The activity of a GOx solution was calculated according to the following equation:

$$
\text { Activity }\left(\frac{U}{m L}\right)=\frac{\Delta D o_{\text {test }} \cdot V}{\varepsilon_{\text {ABTSox }} \cdot 2} \cdot 100
$$

$\Delta D O_{\text {test }}$ is the linear rate of optical density in $A U / m i n, V$ is the final volume in $\mathrm{mL}$ in the spectrophotometric cuvette and $\varepsilon$ is the molar extinction coefficient of $A B T S_{o x}$ at $420 \mathrm{~nm}$ and equals $36,000 \mathrm{M}^{-1} \cdot \mathrm{cm}^{-1}$ Results are given as mean activity $(n>3) \pm$ standard deviation.

The same protocol was used to measure GOx activity after immobilization of the enzyme on the support, except that instead of a solution of free enzyme, $20 \mu \mathrm{L}$ of a siliceous suspension at $0.8 \mathrm{mg} / \mathrm{mL}$ was tested. The resulting suspension $\left(V_{\text {total }}=2 \mathrm{~mL}\right)$ was continuously stirred with a magnetic stirrer while absorbance measurement. The activity of the immobilized enzyme was then expressed as $\mathrm{U} / \mathrm{mg}$ of solid. Relative uncertainty of the activity results can be estimated to $5 \%$, on the base of the standard deviation of three successive measurements of each sample.

The protocols used for the studies of (i) the effect of solvents and temperature on GOx activity (ii) the effect of $\mathrm{pH}$ on GOx adsorption and (iii) the effect of coupling agent concentration on GOx immobilization are available in the Supplementary Information section.

\subsection{Kinetics of glucose oxidation}

The kinetics of the GOx-catalyzed reaction was followed at $30^{\circ} \mathrm{C}$ by continuously monitoring the absorption at $420 \mathrm{~nm}$, for glucose concentrations ranging from $2 \mathrm{mM}$ to $500 \mathrm{mM}$. GOx 
(10 $\mu \mathrm{L}, 0.01 \mathrm{mg} / \mathrm{mL}$ ) was added to a $990 \mu \mathrm{L}$ aerated reaction mix containing $8.6 \mathrm{mM} \mathrm{ABTS}$, $0.01 \mathrm{mg} / \mathrm{mL} \mathrm{HRP}$ and glucose in $100 \mathrm{mM}$ sodium acetate buffer, $\mathrm{pH}$ 6. These conditions allowed us to determine the kinetic parameters $k_{c a t}$ and $K_{M}$ by fitting experimental results with the simple Michealis-Menten model by non-linear regression. The values obtained are in agreement with the literature [42] with $\mathrm{K}_{\mathrm{M}}=26 \mathrm{mM}$ and $\mathrm{k}_{\mathrm{cat}}=380 \mathrm{~s}^{-1}$. GOx concentrations were determined using $\varepsilon_{450 \mathrm{~nm}}=26,000 \mathrm{M}^{-1} \cdot \mathrm{cm}^{-1}, \varepsilon_{280 \mathrm{~nm}}=270,000 \mathrm{M}^{-1} \cdot \mathrm{cm}^{-1}[42]$ and $\mathrm{M}_{\mathrm{w}}=$ 175,000 g. mol ${ }^{-1}$ (dimer molar weight).

\section{Results and discussion}

Three porous siliceous materials with increasing pore dimensions SBA-15, MCF1 and MCF2, respectively, were synthesized for subsequent enzyme immobilization.

\subsection{Characterization of the supports}

The materials were analyzed by nitrogen adsorption-desorption isotherms. The isotherms

(Fig. 1) are type IV curves and form H1 hysteresis loops, typical of mesoporous materials [43]. As expected, the hysteresis of MCFs are larger than that of SBA-15, indicating a much larger pore size distribution. Specific surface area and pore diameters of both SBA-15 and MCFs, shown in Table 1, are in agreement with those reported in the literature $[41,44]$, except for MCF1. In spite, of a similar surface area, e.g., $800 \mathrm{~m}^{2} / \mathrm{g}$, the pore volume as well as the cells and windows size values found in this work were significantly lower than those reported by Stucky et al. As expected, addition of $\mathrm{NH}_{4} \mathrm{~F}$ during the hydrothermal step of MCF2 synthesis resulted in an increase of the window sizes compared to MCF1.

Figure 1. 
The textural parameters of SBA-15 and MCF2 (Table 1) are in agreement with TEM pictures. MCF2 showed disordered sphere-like pores (Fig. 2A) compared to the linear pores of SBA-15 (Fig. 2B). SBA-15 exhibited smaller pores $(5.3 \mathrm{~nm}$ ) than MCF2 that can be described as a network of about $35 \mathrm{~nm}$ diameter cells interconnected by $12 \mathrm{~nm}$ windows. Due to their large cells, MCF materials were confirmed to be promising hosts for glucose oxidase $(6.0 \times 5.2 \times 7.7$ $\mathrm{nm}^{3}$ ) [45]. Moreover, the interconnected windows are large enough (11.7 $\mathrm{nm}$ ) to allow the diffusion of the enzyme inside the material, whereas enzyme immobilization on SBA-15 is likely to take place only on the external surface of silica, as a result of an insufficient pore size to accommodate the protein.

Figure 1.

Table 1. Structural parameters of SBA-15 and MCFs materials

\begin{tabular}{|c|c|c|c|c|c|c|}
\hline Silica support & $\begin{array}{c}\text { TMB/P123 } \\
\text { (g/g) }\end{array}$ & $\begin{array}{c}\mathrm{NH}_{4} \mathrm{~F}(\mathrm{mg}) / \\
\mathrm{P} 123(\mathrm{~g})\end{array}$ & $\begin{array}{c}\mathrm{S}_{\mathrm{BET}}^{\mathrm{a}} \\
\left(\mathrm{m}^{2} / \mathrm{g}\right)\end{array}$ & $\begin{array}{c}D_{p}^{b} \text { or } D_{c}^{c} \\
(n m)\end{array}$ & $\begin{array}{l}D_{w}^{c} \\
(n m)\end{array}$ & $\begin{array}{l}\text { Pore } \\
\text { volume } \\
\left(\mathrm{cm}^{3} / \mathrm{g}\right)\end{array}$ \\
\hline SBA-15 (this work) & 0 & 0 & 904 & 5.3 & - & 1.19 \\
\hline SBA-15 [58] & 0 & 0 & 850 & 5.8 & - & 1.17 \\
\hline MCF1 (this work) & 1.0 & 0 & 810 & 22.1 & 5.3 & 1.17 \\
\hline MCF1[55] & 1.0 & 0 & 800 & 33.0 & 10.7 & 2.0 \\
\hline MCF2 (this work) & 1.0 & $24 \mathrm{mg} / 2 \mathrm{~g}$ & 639 & 35.4 & 11.7 & 2.4 \\
\hline MCF2 [55] & 1.0 & $24 \mathrm{mg} / 2 \mathrm{~g}$ & 625 & 32.2 & 16.5 & 2.2 \\
\hline \multicolumn{7}{|c|}{ a,b,c Calculated using Brunauer-Emmett-Teller BET, Barrett, Joyner and Halenda BJH and modified Broekr } \\
\hline
\end{tabular}


Post-synthesis modification of SBA-15 or MCF silica was then performed using the reaction of APTES with their silanol groups thus allowing the preparation of SBA-15- $\mathrm{NH}_{2}, \mathrm{MCF}-\mathrm{NH}_{2}$ and MCF2- $\mathrm{NH}_{2}$ [46]. The presence of the aminopropyl functions on the surface of the supports will allow the subsequent covalent grafting of GOx through the formation of an amide bond between the amine functions and the external carboxylic groups of the enzyme. FTIR spectra of SBA-15-NH2, MCF1-NH $\mathrm{NH}_{2}$ and MCF2-NH $\mathrm{NH}_{2}$ samples showed $\mathrm{N}-\mathrm{H}$ stretching and $\mathrm{N}-\mathrm{H}$ deformation bands at $3,400 \mathrm{~cm}^{-1}$ and $1,600 \mathrm{~cm}^{-1}$, respectively (Fig. $\mathrm{S} 1$ in the supplementary information). These results thus, indicate the presence of amine groups on SBA-15 and MCF materials whose surface densities (Table 2) were calculated from TG analysis (data shown Fig. S2). The amount of grafted APTES increased from $1.65 \mathrm{mmol}$ to $2.06 \mathrm{mmol}$ for SBA-15 and MCF2 respectively, leading to a much higher density of the amino groups for MCF2, as a consequence of the lower surface area of the latter support. With an amine surface density of $1.9 \pm 0.6$ molecules per $\mathrm{nm}^{2}$ and supposing that each aminopropyl chain is grafted via at least two Si-O-Si bonds, half of the available silanol groups on the MCF2 surface would have reacted.

Table 2. Quantification of the $-\mathrm{NH}_{2}$ groups on the surface of SBA-15- $\mathrm{NH}_{2}, \mathbf{M C F 1}-\mathrm{NH}_{2}$ and $\mathbf{M C F 2}-\mathrm{NH}_{2}$.

\begin{tabular}{|c|c|c|c|c|}
\hline Support & Weight loss ${ }^{\mathrm{a}}(\%)$ & $\begin{array}{c}-\mathrm{NH}_{2} \text { loaded } \\
\text { (mmol/g) }\end{array}$ & $\mathrm{S}_{\mathrm{BET}}\left(\mathrm{m}^{2} / \mathrm{g}\right)$ & $-\mathrm{NH}_{2}$ density $\left(/ \mathrm{nm}^{2}\right)$ \\
\hline SBA-15-NH & 17.3 & 1.65 & 904 & $1.05 \pm 0.2$ \\
\hline MCF1-NH 2 & 19.5 & 1.86 & 810 & $1.4 \pm 0.4$ \\
\hline MCF2-NH ${ }_{2}$ & 21.3 & 2.06 & 639 & $1.9 \pm 0.6$ \\
\hline
\end{tabular}




\subsection{GOx immobilization}

Two methods were used to immobilize glucose oxidase: physical adsorption and covalent grafting. They were then compared in terms of efficiency, i.e amount of bound active enzyme and stability.

\subsubsection{Adsorption}

Adsorption of GOx on functionalized MCF2- $\mathrm{NH}_{2}$ was performed in $100 \mathrm{mM}$ acetate buffer at $\mathrm{pH}=6$, at room temperature. As expected, the more GOx in the supernatant, the more active enzyme was adsorbed on the porous support $[47,48]$. These experimental data could be accurately described according to a Langmuir model (S3). From fitting of the experimental data, it could be calculated that the maximum immobilized GOx activity was around 10.4 $\mathrm{U} / \mathrm{mg}$ of solid. Alternatively, the amount of immobilized enzyme was determined by thermogravimetry (Fig. 3).

Figure 3

Analysis of the silica materials functionalized with aminopropyl groups was first performed as a negative control. When increasing the temperature, two successive weight losses corresponding to two maximum values on the derivative weight profile at $50^{\circ} \mathrm{C}$ and around $320^{\circ} \mathrm{C}$ were observed. It can be assumed that they result from water loss and combustion of aminopropyl groups of silica surface, respectively. After enzyme adsorption, these two weight variations also took place at the same temperature whereas an additional weight loss event could be noticed around $150^{\circ} \mathrm{C}$ that could be assigned to the enzyme thermal degradation. This latter weight loss corresponds to $4.2 \%$ of the sample initial mass, meaning that $42 \mu \mathrm{g}$ of GOx was adsorbed on $1 \mathrm{mg}$ of the MCF2-NH $\mathrm{N}_{2}$ support. On the other hand, the 
supported GOx activity measured from the hydrogen peroxide quantification by spectrophotometry was estimated to $4.5 \mathrm{U}$ per mg of MCF2- $\mathrm{NH}_{2}$. These activity and amount measurements of adsorbed GOx allows to calculate that the specific activity of immobilized GOx is $107 \mathrm{U} / \mathrm{mg}$. Knowing that the specific activity of free GOx is $120 \mathrm{U} / \mathrm{mg}$, it can thus be deduced that GOx retained about $90 \%$ of its specific activity after adsorption, and consequently, that immobilization induce a significant but limited denaturation of the enzyme. Denaturation was also rather slight in case of covalently immobilization of GOx: the activity of the supported enzyme was $5 \mathrm{U} / \mathrm{mg}$ of $\mathrm{MCF} 2-\mathrm{NH}_{2}$ whereas the amount of immobilized GOx deduced from TGA was $46 \mu \mathrm{g} / \mathrm{mg}$. The specific activity of covalently immobilized GOx is thus $109 \mathrm{U} / \mathrm{mg}$.

Additionally, it can be deduced from the maximum activity of supported GOx (9.2 U/mg) and the specific activity of the enzyme that the maximal enzyme coverage was $2.6 \times 10^{17}$ molecules per gram of solid, i.e a surface coverage around $13 \mathrm{~m}^{2} \mathrm{~g}^{-1}$ (considering the GOx surface around $50 \mathrm{~nm}^{2}$ ) for adsorbed GOx. The total surface of the support being $639 \mathrm{~m}^{2} \cdot \mathrm{g}^{-1}$, GOx thus covered only $2 \%$ of the total available surface. It can also be noticed that the amino group density on the support surface $\left(2.06 \times 10^{3} \mu \mathrm{mol} . \mathrm{g}^{-1}\right.$ for MCF2-NH 2$)$ is about four orders of magnitude higher than the immobilized protein density $\left(1.9 \times 10^{-1} \mu \mathrm{mol} . \mathrm{g}^{-1}\right.$ for an initial free GOx to MCF2- $\mathrm{NH}_{2}$ of $2.8 \mu \mathrm{mol} . \mathrm{g}^{-1}$ ), thus excluding an amino group shortage for covalent bonding. The same trend was observed by Zhang et al. [24] with MCF1-NH $\mathrm{N}_{2}$ type silica: the GOx loading was almost five hundred times lower than the amino group density. One explanation could be related to the size of the enzyme whose diffusion inside the pores could be hindered. 
In order to check the influence of $\mathrm{pH}$ on protein loading, adsorption experiments were performed with MCF2- $\mathrm{NH}_{2}$ in a $\mathrm{pH}$ range from 4 to 8 . Fig.4 shows that GOx adsorption increased when increasing $\mathrm{pH}$ from 4 to 5 and that a further increase in $\mathrm{pH}$ led to a decrease of the activity on the solid. A maximum was observed around $\mathrm{pH}=5$. The overall profile of GOx adsorption as a function of $\mathrm{pH}$ can be explained by electrostatic interactions between the protein and the support. According to zeta potential measurements (Fig. S4 in the supplementary information), the PZC of the functionalized solid was estimated around 8.5. Its overall surface charge is positive for $\mathrm{pH}$ lower than 8.5 while the enzyme is overall negatively charged at $\mathrm{pH}$ above its isoelectrical point, i.e 4.2 [42]. The number of negative charges on the enzyme surface even increases when increasing the $\mathrm{pH}$ to around 5, i.e until the carboxylic residues on the protein are all deprotonated, leading to a maximal adsorption with the positively charged support. Above this $\mathrm{pH}$, deprotonation of remaining silanol groups (two populations with pKa values of 4.5 and 8.5 [31]) on the surface takes place, thus decreasing the electrostatic interaction strength between the support and the protein, and consequently the protein adsorption decreased. The amount of active GOx immobilized by adsorption thus strongly depends on the supernatant $\mathrm{pH}$, which can lead to the protein leaching when $\mathrm{pH}$ is not carefully controlled. On the other hand, one can take advantage of the low adsorption of GOx at high pH to eliminate the enzyme that would not be covalently bonded on the support by washing as described below.

Figure 4.

\subsubsection{Covalent immobilization}

GOx was covalently linked to the supports via amide bonds between the amino groups on the solid and the carboxylic acid residues of the protein. An EDC and NHS mixture was used 
as a coupling agent to activate the carboxylic groups on the enzyme surface. This procedure is widely used to link proteins covalently on siliceous substrates [49] or even for GOx immobilization, for example on modified metallic nanotubes [50]. Fig. 5 shows the enzymatic activity of the grafted MCF2- $\mathrm{NH}_{2}$ solid as a function of the initial ratio of GOx to solid in the presence or not of coupling agents and following two different washing procedures. When the solid was washed at $\mathrm{pH}=6$, almost no difference was observed between the amount of immobilized active GOx, in the presence or in the absence of coupling agents, except at high initial concentrations of GOx (Fig. 5A). For an initial GOx/solid ratio above 30-40 U.mg ${ }^{-1}$, the amount of immobilized active GOx in the absence of EDC/NHS reached a plateau around 8 U.mg ${ }^{-1}$, whereas it remained lower than $6 \mathrm{U} \cdot \mathrm{mg}^{-1}$ in the presence of coupling agent. When GOx was only adsorbed, the activity measured on the support fell drastically below 1 U. $\mathrm{mg}^{-1}$ after washing the solid at $\mathrm{pH}=8$ (Fig. 5B).

Figure 5

In the presence of coupling agents, the amount of immobilized active enzyme also decreased compared to that obtained when washing at $\mathrm{pH}=6$, as a result of the desorption of the noncovalently bound proteins. However, it remained significantly higher than when GOx was immobilized only by adsorption (c.a. 1 U. $\mathrm{mg}^{-1}$ activity). Out of the total $5 \mathrm{U} . \mathrm{mg}^{-1}$ activity of immobilized protein, it can thus be concluded that around $4 \mathrm{U}$ of GOx can be covalently bound to $1 \mathrm{mg}$ of MCF2-NH when using $100 \mathrm{U} \cdot \mathrm{mg}^{-1}$ of solid as an initial free protein concentration.

Immobilization experiments were carried out for SBA15- $\mathrm{NH}_{2}, \mathrm{MCF} 1-\mathrm{NH}_{2}$ and MCF2- $\mathrm{NH}_{2}$ in order to further assess the efficiency of protein loading depending on the mesoporous material pore size. Fig. 6 clearly demonstrates the influence of the pore size on the protein 
loading. In the whole range of initial protein concentration studied $(0<$ initial GOx/solid ratio $<100)$, SBA15- $\mathrm{NH}_{2}$ is the less efficient support. The GOx loading on this support overall increases with initial GOx concentration, but reaches a maximum at $2 \mathrm{U} \cdot \mathrm{mg}^{-1}$.

Figure 6.

Comparison between the two mesocellular materials, MCF1- $\mathrm{NH}_{2}$ and MCF2- $\mathrm{NH}_{2}$, showed that protein loading was higher for MCF2- $\mathrm{NH}_{2}$, except at the lowest enzyme concentration. The similar behavior of MCF1-NH 2 and MCF2-NH $\mathrm{N}_{2}$ for initial GOx/solid ratio $<10$ could result from the preferential immobilization of the enzyme on the externally addressable surface of the materials in presence of a low GOx concentration. With higher protein concentrations in solution, the protein loading increased for both materials but the activity measured on the support was higher for MCF2- $\mathrm{NH}_{2}$ than for MCF1-NH $\mathrm{N}_{2}, 5 \mathrm{U} / \mathrm{mg}$ and $2 \mathrm{U} / \mathrm{mg}$, respectively. It can be hypothesized that at high initial concentrations of GOx, protein diffusion inside the larger interconnected cells and windows of MCF2-NH $\mathrm{NH}_{2}$ is facilitated. Indeed, the pores and the windows sizes of MCF2- $\mathrm{NH}_{2}$ are larger than the protein, thus allowing a higher protein loading. In contrast, mean pore diameters of both SBA15-NH and MCF1- $\mathrm{NH}_{2}$ silica are smaller than the protein, so that GOx cannot be accommodated inside the pores, even as a monomer whose dimensions are $6.0 \times 5.2 \times 3.7 \mathrm{~nm}^{3}$. These results suggest that some GOx could be housed in cells within the MCF2-NH 2 support. Szymańska et al. [17] showed the same trend for invertase covalently immobilized using glutaraldehyde: the protein content was twice as large on MCF as on SBA-15.

The highest activity being measured on $\mathrm{MCF} 2-\mathrm{NH}_{2}$, this support is thus likely to be the best candidate for GOx immobilization for hydrogen peroxide production. This catalytic activity of GOx was assayed by using the rate of hydrogen peroxide production by GOx at saturating 
concentration of glucose, i.e. 0.5 mol. $\mathrm{L}^{-1}$. The Michaelis Menten constant $\mathrm{K}_{\mathrm{M}}$ of the $\mathrm{GOx}$ enzyme immobilized on MCF2- $\mathrm{NH}_{2}$ was determined to further characterize its efficiency. The $\mathrm{K}_{M}$ values for immobilized and free GOx were $28.8 \pm 2.8 \mathrm{mM}$ and $29.7 \pm 2.8 \mathrm{mM}$, respectively, lin accordance with value reported in the literature for free GOx [42]. The affinity of immobilized GOx for glucose thus remains unchanged after immobilization. One hypothesis could be that the location of the enzyme inside the pores of the support preserves the availability of the enzyme for its substrate and that there is no substrate diffusion limitation.

\subsection{Stability studies of immobilized GOx on $\mathrm{MCF} 2-\mathrm{NH}_{2}$}

Ti-based catalytic epoxidation of alkenes currently takes place above room temperature and in organic solvents such as methanol or acetonitrile. For these reasons, stability studies of GOx had to be performed up to $50^{\circ} \mathrm{C}$ and in hydro-organic mixtures.

\subsubsection{Enzyme thermal stability}

The stability of both free and immobilized GOx to denaturation after a short incubation time at a given temperature was investigated. It can be seen from Fig. 7A that the enzyme activity remained rather unchanged from 30 to $45^{\circ} \mathrm{C}$ and then dropped drastically for higher temperatures. The thermal stability of immobilized GOx was only slightly higher than that of the free enzyme. Thus, using short incubation time conditions at a given temperature, it can be concluded that the immobilization of GOx on MCF2-NH $\mathrm{NH}_{2}$ does not allow protecting the enzyme from denaturation. However, thermal stability studies involving longer incubation times (Fig. 7B) clearly emphasized the advantage of using immobilized GOx. Up to $80 \%$ of its initial activity was retained after 44 hours storage at $50^{\circ} \mathrm{C}$, whereas the activity of the free enzyme drops quickly to hardly $10 \%$ of its initial value. A further $120 \mathrm{~h}$ storage period at $9^{\circ} \mathrm{C}$ 
showed that the observed partial denaturation at $50^{\circ} \mathrm{C}$ was not reversible but confirmed the fact that the immobilized enzyme is much more active than the free one.

Figure 7.

\subsubsection{Enzyme stability in hydro-organic mixtures}

The storage stability of immobilized GOx in the presence of acetonitrile or methanol was studied for $4 \mathrm{~h}$ at room temperature (Fig. $8 \mathrm{~A}$ ) and $50^{\circ} \mathrm{C}$ (Fig. 8B).

Figure 8.

Storage of GOx at room temperature in the presence of these solvents did not show any significant effect regarding activity up to $50 \%$ of organic solvent content as can be seen from Fig. 8A. For higher percentages, the decrease of activity turned out to be more important in methanol than in acetonitrile: less than $10 \%$ of remaining activity compared to $75 \%$, respectively. Moreover, it has to be noted that the activities of immobilized and free GOx in a given solvent (methanol or acetonitrile) were very similar.

On the other hand, storage of $\mathrm{GOx}$ at $50^{\circ} \mathrm{C}$ in the presence of methanol or acetonitrile (Fig. 8B) did show important effects on the enzyme behavior. Indeed, for both acetonitrile and methanol, the free enzyme was completely denatured above $20 \%$ of solvent whereas when immobilized, the GOx stability was significantly improved. The stabilization effect however depended on the solvent. In contrast to room temperature experiments, immobilized GOx showed higher activities when the solid was stored in $\mathrm{MeOH}$ compared to acetonitile. Up to 
$50 \% \mathrm{v} / \mathrm{v}$ of organic solvent, activity of the immobilized protein stored in $\mathrm{MeOH}$ medium was up to 4-fold higher than in $\mathrm{CH}_{3} \mathrm{CN}$ medium for a given solvent percentage.

Obviously, immobilization on MCF protects the enzyme against solvent induced denaturation, presumably as the result of the reduction of interferences of the organic solvent with hydrogen bonds of the 3D structure of the enzyme. Another explanation of the protein stabilization upon immobilization could be the induced rigidification of its structure, mainly if covalent multipoint attachment is achieved, as reported by Rodrigues et al. [51] in their review.

\section{Conclusion}

In this study, immobilization of glucose oxidase was compared on amino-functionalized siliceous mesoporous materials with large surface areas and either well-ordered pore channels (SBA-15) or disordered connected meso-cells (MCF). It was shown that MCF with both cells and windows diameters larger than the dimensions of the enzyme led to the immobilization of the highest quantity of active GOx compared to materials with windows or pore dimensions not large enough to allow protein diffusion inside the material. Immobilization methods based on adsorption or covalent coupling (amide bond) were compared and experimental conditions were controlled to minimize adsorption, mostly by adjusting $\mathrm{pH}$, so that electrostatic interactions between the amino-functionalized support and the protein should be unfavorable. In such conditions, at least $80 \%$ of the immobilized GOx could be covalently grafted on the support, thus reducing the leaching of the protein. The immobilized GOx exhibited a catalytic efficiency similar to that of the free GOx, based on the determination of the Michaelis-Menten constant, $\mathrm{K}_{\mathrm{M}}$. The specific ativity of both adsorbed and covalently immobilized GOx calculated from thermogravimetric analysis and 
activity measurement was only $10 \%$ lower than the one of free GOx, showing that the immobilization process induced only slight denaturation of the enzyme. Despite of this rather low protein loading, the activity of the immobilized enzyme is relevant for biotechnological applications. As an example, a hydrogen peroxide production rate of 0.1 $\mathrm{mmol} / \mathrm{min}$ can be obtained in acetate buffer with $20 \mathrm{mg}$ of the optimized material (MCF2$\mathrm{NH}_{2}$ ). For the epoxidation application targeted, the stability of covalently immobilized GOx was investigated at $50^{\circ} \mathrm{C}$ in acetate buffer as well as at 25 or $50^{\circ} \mathrm{C}$ in acetate buffer/organic solvents mixtures. After 4 hours in acetate buffer at $50^{\circ} \mathrm{C}$, immobilized GOx was found to be more stable than its free counterpart (only activity $20 \%$ loss compared to $90 \%$, respectively). The activity loss in such conditions was attributed to the irreversible denaturation of the protein. Both free and immobilized GOx showed a rather good stability after their room temperature incubation in buffer/methanol or acetonitrile mixtures with less than $50 \mathrm{v} / \mathrm{v} \%$ of organic solvent. For higher solvent percentage values, immobilized GOx turned out to be more stable in the presence of acetonitrile than of methanol at room temperature whereas the opposite result was observed at $50^{\circ} \mathrm{C}$. These results pave the way to further experiments coupling enzymatic production of hydrogen peroxide and its subsequent utilization in an environmental friendly oxidation such as epoxidation of bulky alkenes catalyzed by Ti(IV) .

\section{Acknowledgements}

The financial support from the French Ministry of Research and Higher Education (MESR) is gratefully acknowledged.

\section{References}

[1] F. Cavani, J.H. Teles, ChemSusChem 2 (2009) 508-534. 
[2] P.N.R. Vennestrøm, C.H. Christensen, S. Pedersen, J.-D. Grunwaldt, J.M. Woodley, ChemCatChem 2 (2010) 249-258.

[3] G. Sienel, R. Rieth, K.T. Rowbottom, Ullmann's encyclopedia of industrial chemistry, WileyVCH, 2003, p. 272.

[4] V. Paunovic, V. Ordomsky, M. Fernanda Neira D’Angelo, J.C. Schouten, T.A. Nijhuis, J Catal 309 (2014) 325-332.

[5] N. O'Callaghan, J.A. Sullivan, Appl Catal, B 146 (2014) 258-266.

[6] A. Prieto, M. Palomino, U. Díaz, A. Corma, Catal Today 227 (2014) 87-95.

[7] K.-H. Tong, K.-Y. Wong, T.H. Chan, Tetrahedron 61 (2005) 6009-6014.

[8] P.N.R. Vennestrøm, E. Taarning, C.H. Christensen, S. Pedersen, J.-D. Grunwaldt, J.M. Woodley, ChemCatChem 2 (2010) 943-945.

[9] M. Yabushita, H. Kobayashi, A. Fukuoka, Appl Catal, B 145 (2014) 1-9.

[10] S.B. Bankar, M.V. Bule, R.S. Singhal, L. Ananthanarayan, Biotechnol Adv 27 (2009) 489-501.

[11] R.A. Sheldon, Adv Synth Catal 349 (2007) 1289-1307.

[12] K.-C. Kao, C.-H. Lee, T.-S. Lin, C.-Y. Mou, J Mater Chem 20 (2010) 4653.

[13] J. Zhao, Y. Wang, G. Luo, S. Zhu, Bioresour Technol 101 (2010) 7211-7217.

[14] H. Sun, X. Ying Bao, X.S. Zhao, Langmuir 25 (2009) 1807-1812.

[15] S. Hudson, J. Cooney, B.K. Hodnett, E. Magner, Chem Mater 19 (2007) 2049-2055.

[16] D. Jung, C. Streb, M. Hartmann, Int J Mol Sci 11 (2010) 762-778.

[17] K. Szymańska, J. Bryjak, A.B. Jarzębski, Top Catal 52 (2009) 1030-1036.

[18] H. Gustafsson, E.M. Johansson, A. Barrabino, M. Oden, K. Holmberg, Colloids Surf, B 100 (2012) 22-30.

[19] A. Rekuć, J. Bryjak, K. Szymańska, A.B. Jarzębski, Process Biochem 44 (2009) 191-198.

[20] A.B. Jarzębski, K. Szymańska, J. Bryjak, J. Mrowiec-Białoń, Catal Today 124 (2007) 2-10.

[21] D. Jung, M. Hartmann, Catal Today 157 (2010) 378-383.

[22] K. Szymańska, J. Bryjak, J. Mrowiec-Białoń, A.B. Jarzębski, Microporous Mesoporous Mater 99 (2007) 167-175.

[23] J. Li, G. Yin, Y. Ding, X. Liao, X. Chen, Z. Huang, Y. Yao, X. Pu, J Biosci Bioeng 116 (2013) 555-

561.

[24] X. Zhang, R.-F. Guan, D.-Q. Wu, K.-Y. Chan, J Mol Catal B: Enzym 33 (2005) 43-50.

[25] C. Jun, H. Tianxi, F. Xuemei, Talanta 100 (2012) 419-424.

[26] G. Zhou, K.K. Fung, L.W. Wong, Y. Chen, R. Renneberg, S. Yang, Talanta 84 (2011) 659-665.

[27] J. Deere, E. Magner, J.G. Wall, B.K. Hodnett, Chem Commun (2001) 465-465.

[28] T. Yokoi, H. Yoshitake, T. Tatsumi, J Mater Chem 14 (2004) 951.

[29] Z. Zhou, M. Hartmann, Top Catal 55 (2012) 1081-1100.

[30] R.A. Sheldon, S. van Pelt, Chem Soc Rev 42 (2013) 6223-6235.

[31] A. Rimola, D. Costa, M. Sodupe, J.F. Lambert, P. Ugliengo, Chem Rev 113 (2013) 4216-4313.

[32] D. Gaffney, J. Cooney, E. Magner, Top Catal 55 (2012) 1101-1106.

[33] P. Reis, T. Witula, K. Holmberg, Microporous Mesoporous Mater 110 (2008) 355-362.

[34] D. Jung, M. Paradiso, M. Hartmann, J Mater Sci 44 (2009) 6747-6753.

[35] S.-i. Matsuura, R. Ishii, T. Itoh, T. Hanaoka, S. Hamakawa, T. Tsunoda, F. Mizukami, Microporous Mesoporous Mater 127 (2010) 61-66.

[36] D. Jung, M. Paradiso, D. Wallacher, A. Brandt, M. Hartmann, ChemSusChem 2 (2009) 161-

164.

[37] L. Betancor, F. Lopez-Gallego, A. Hidalgo, N. Alonso-Morales, G. Dellamora-Ortiz, J.M. Guisan, R. Fernandez-Lafuente, J Biotechnol 121 (2006) 284-289.

[38] P. Schmidt-Winkel, W. Lukens, D. Zhao, P. Yang, B. Chmelka, G. Stucky, J Am Chem Soc 121 (1999) 254-255.

[39] E.P. Barett, L.G. Joyner, P.P. Halend, J Am Chem Soc 73 (1951) 373-380.

[40] W. Lukens, P. Schmidt-Winkel, D. Zhao, J. Feng, G. Stucky, Langmuir 15 (1999) 5403-5409. 
[41] P. Schmidt-Winkel, J.W.W. Lukens, P. Yang, D.I. Margolese, J.S. Lettow, J.Y. Ying, G.D. Stucky, Chem Mater 12 (2000) 686-696.

[42] C.M. Wong, K.H. Wong, X.D. Chen, Appl Microbiol Biotechnol 78 (2008) 927-938.

[43] S.J. Gregg, K.S.W. Sing, Adsorption, surface area, and porosity, Academic Press, 1991.

[44] D. Zhao, Q. Huo, J. Feng, B. Chmelka, G.D. Stucky, J Am Chem Soc 120 (1998) 6024-6036.

[45] H.J. Hecht, H.M. Kalisz, J. Hendle, R.D. Schmid, D. Schomburg, J Mol Biol 229 (1993) 153-172.

[46] K.C. Vrancken, K. Possemiers, P. Van Der Voort, E.F. Vansant, Colloids and Surfaces 98 (1995) 235-241.

[47] V. Gascón, C. Márquez-Álvarez, R.M. Blanco, Appl Catal, A 482 (2014) 116-126.

[48] E. Silva Mojica, M. Lohrasbi, S.S.C. Chuang, Top Catal 57 (2014) 1490-1497.

[49] P. Tengvall, E. Jansson, A. Askendal, P. Thomsen, C. Gretzer, Colloids Surf, B 28 (2003) 261-

272.

[50] M. Delvaux, S. Demoustier-Champagne, Biosens Bioelectron 18 (2003) 943-951.

[51] R.C. Rodrigues, C. Ortiz, A. Berenguer-Murcia, R. Torres, R. Fernandez-Lafuente, Chem Soc Rev 42 (2013) 6290-6307. 
Figures captions

Figure 1. $\mathrm{N}_{2}$ adsorption/desorption isotherms $\left(-196^{\circ} \mathrm{C}\right)$ of SBA-15 (square), MCF1 (triangle) and MCF2 (circle).

Figure 2. TEM images of silica MCF2 (A) and SBA-15 (B) at the same scale.

Figure 3. Thermogravimetric analysis of $\mathrm{MCF} 2-\mathrm{NH}_{2}$ without GOx (Dark gray line), with adsorbed GOx (Light gray lines) and with covalently immobilized GOx (Black lines from $24^{\circ} \mathrm{C}$ to $900^{\circ} \mathrm{C}$, under $100 \mathrm{~mL} / \mathrm{min}$ of air with a ramp rate of $10^{\circ} \mathrm{C} / \mathrm{min}$.

Figure 4. Influence of $\mathrm{pH}$ on $\mathrm{GOx}$ adsorption on MCF2-NH $\mathrm{NH}_{2}$ (20 $\mathrm{mg}$ of solid support was dispersed in $25 \mathrm{~mL}$ of $\mathrm{GOx}(62.5 \mathrm{U} / \mathrm{mL})$ in $100 \mathrm{mM}$ acetate buffer overnight at room temperature.)

Figure 5. GOx activity on MCF2- $\mathrm{NH}_{2}$ as a function of the $\mathrm{GOx} /$ solid initial ratio, for adsorption (square) and covalent (circle) experiments i.e without and with coupling agent, respectively. After (A): two washes at $\mathrm{pH}=6,(\mathrm{~B})$ : two additional washes at $\mathrm{pH}=8$. For the immobilization step, $20 \mathrm{mg}$ of solid was dispersed in $4 \mathrm{~mL} 10 \mathrm{mM}$ phosphate buffer $\mathrm{pH}=6$ for adsorption and $4 \mathrm{~mL}$ phosphate buffer $\mathrm{pH}=7.6$ for the covalent grafting step. For the covalent grafting (circle), coupling agents/GOx molar ratio is 800 .)

Figure 6. Activity of immobilized GOx as a function of initial GOx/solid molar ratio for three different supports: SBA-15- $\mathrm{NH}_{2}$ (triangle), $\mathrm{MCF} 1-\mathrm{NH}_{2}$ (circle) and $\mathrm{MCF} 2-\mathrm{NH}_{2}$ (square). C.A./initial GOX concentrations ratio was 400. EDC and NHS concentrations were identical and ranged between 0.032 and $0.609 \mathrm{mM} .1 \mathrm{mg}$ of solid was suspended in $1.6 \mathrm{~mL}$ of phosphate buffer $\mathrm{pH}=7.6$, for the grafting step. Materials wahsing after GOx immobilization was perforemd at $\mathrm{pH} 8$.

Figure 7. Thermal stability in aqueous media of free (black square) and immobilized GOx on MCF2- $\mathrm{NH}_{2}$ (white circle). A : Activity after short incubation time B : Activity after storage at $50^{\circ} \mathrm{C}$. Solid was suspended in $100 \mathrm{mM}$ acetate buffer $(\mathrm{pH} 6)$.

Figure 8. Stability of free (square) or immobilized GOx on MCF2-NH2(circle) stored for 4 hours at room temperature $(A)$ or $50^{\circ} \mathrm{C}(\mathrm{B})$ in the presence of water $/ \mathrm{CH}_{3} \mathrm{CN}$ (white) and water/MeOH (black) mixtures. C.A./initial GOx concentrations ratio was 350. Initial glucose and EDC (or NHS) concentrations were $0.5 \mathrm{~g} / \mathrm{L}$ and $1 \mathrm{mM}$, respectively, for $20 \mathrm{mg}$ of tested solid. 


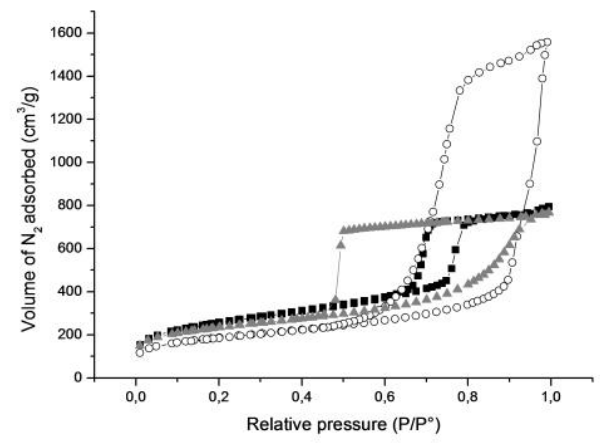

Figure 1 


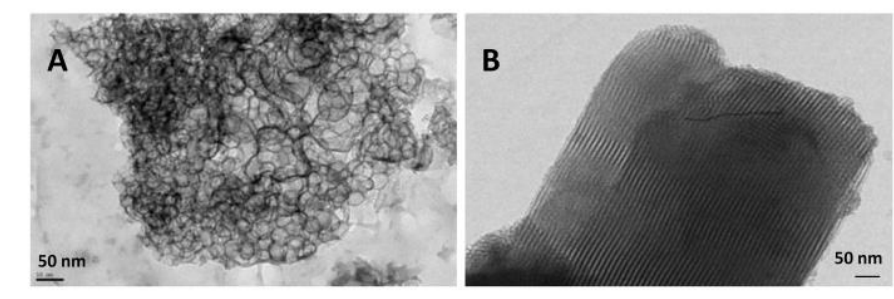

Figure 2 


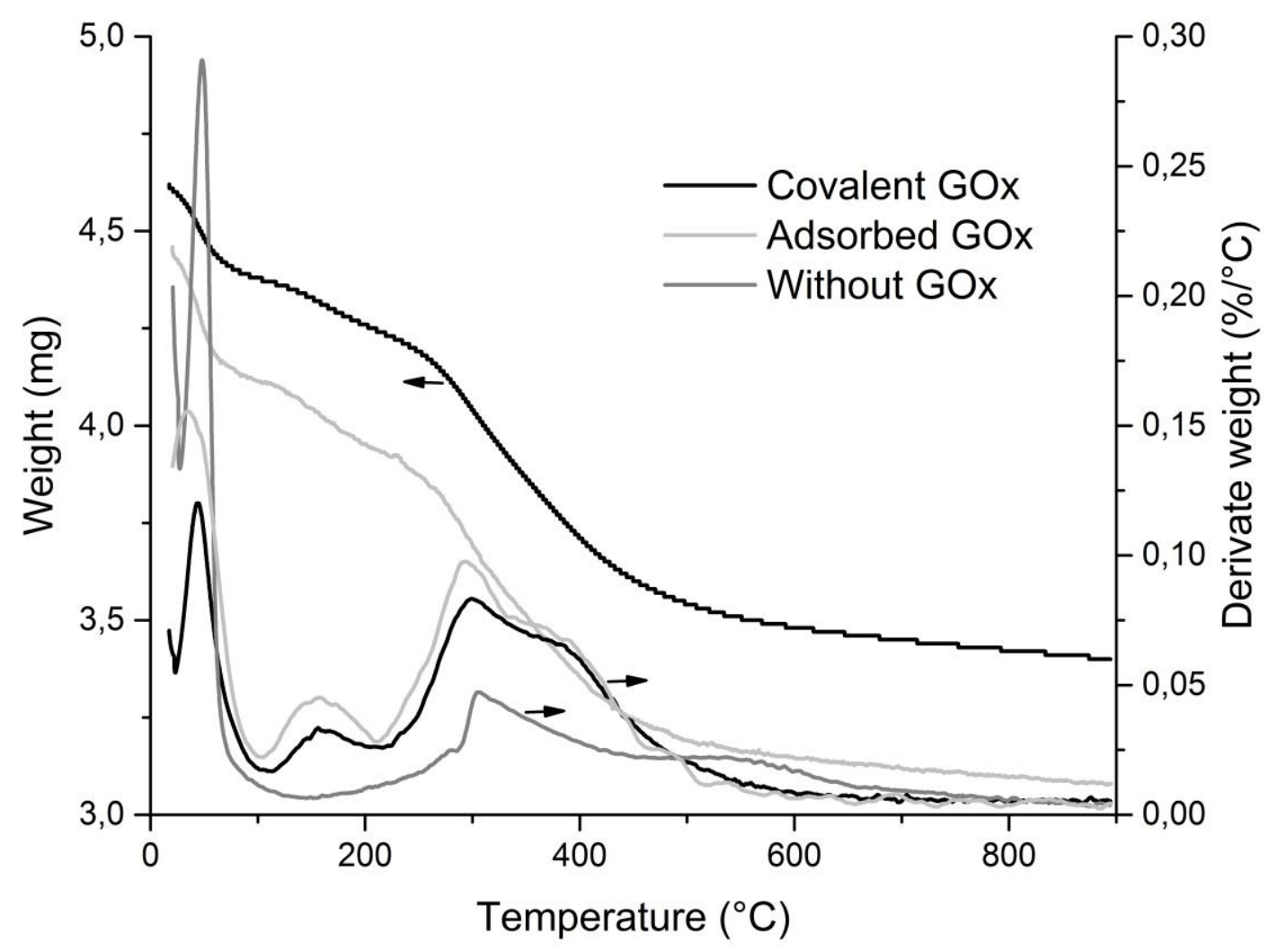

Figure 3 


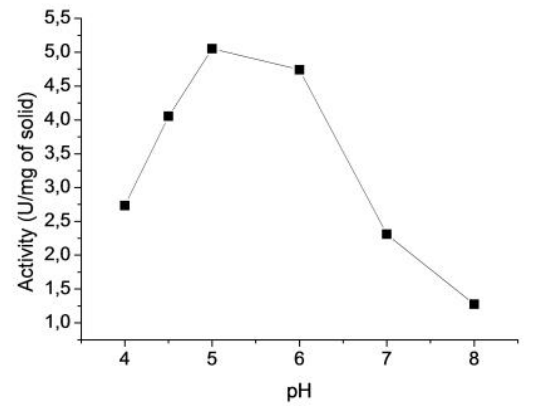

Figure 4 

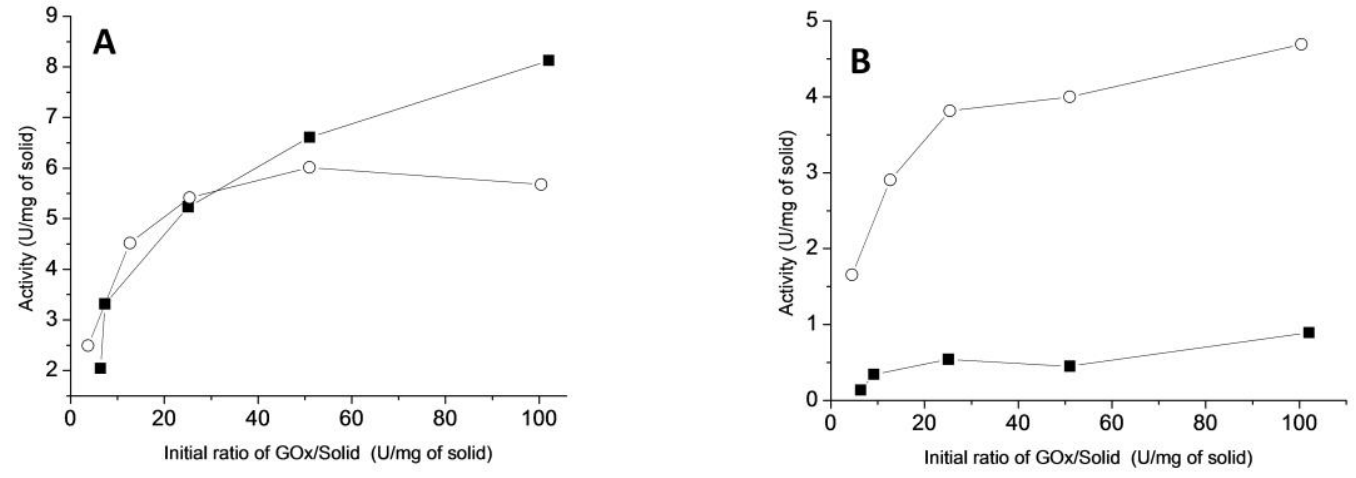

Figure 5 


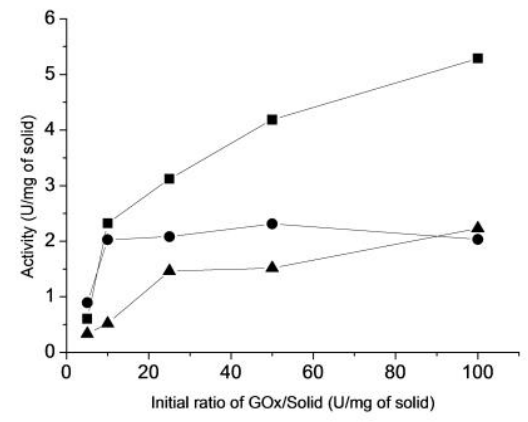

Figure 6 
A
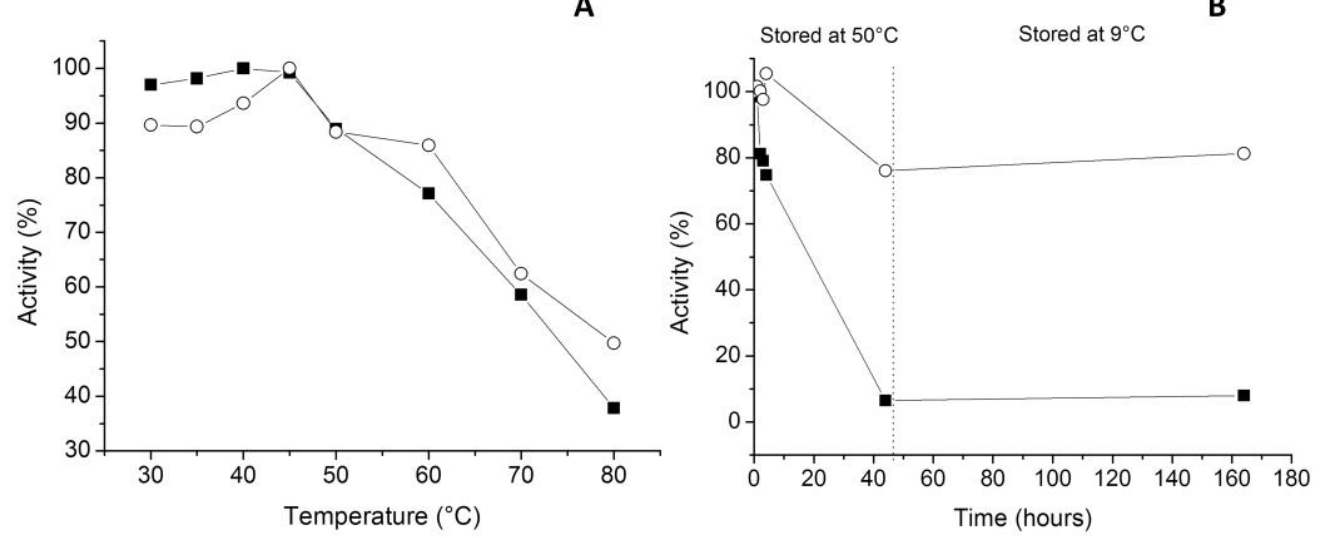

Figure 7 

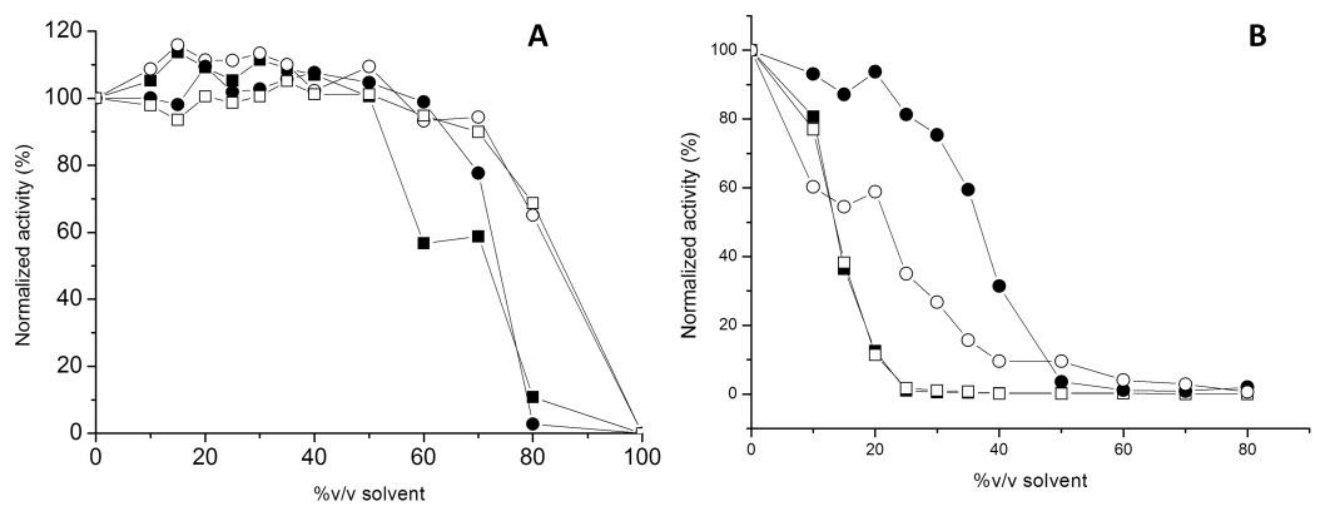

Figure 8 